\title{
Contemplation and rationality. The sacred dimension of theology
}

\begin{abstract}
This article raises the question of the mutual relation between theology and prayer. Theology is knowledge about God - the Holiest - and should carry out research in a holy manner, contributing to the holiness of the person who is connected with theology as a teacher or a student. The question of the relation between theology and prayer belongs to the most fundamental issues concerning the method of theology to which we should constantly refer as to an important source of guidelines for today. This article first focuses on certain statements which appeared in the past centuries and which discussed the relation between theology and prayer, trying to find the adequate approach to the spiritual and scientific situation in the field of theology in those times. After this introduction, it presents the view that prayer may be used in service of theology. Theology, on the other hand, in its full and traditional sense, is total and complete only then, when it constitutes the foundation of piety and leads to prayer. Theology through prayer can permeate the inner life opening itself to the state when we belong to God who resides in our heart.
\end{abstract}

\section{Keywords}

Jesus Christ, theology, prayer, contemplation, spirituality, rationality. 
"Faith is strengthened by the fear of God, and continence strengthens this fear; through perseverance and hope continence becomes unshakeable, and from them is born freedom from passions (apatheia) which has charity (agape) for a daughter; charity is the door to natural knowledge, then theology succeeds it and finally comes beatitude."

Evagrius Ponticus ${ }^{1}$

The question of the mutual and directly internal relation between theology and prayer is as old as theology itself. This relation is clearly reflected in the traditional and solemn phrase sacra theologia which is applied when we speak about theology. This phrase emphasises, that it is the knowledge concerning God - the Holiest, and that all the research carried out within the study should be holy in manner. This may thus contribute, to the holiness of the person who is connected with theology as a teacher or a student. The question of the relation between theology and prayer belongs to the most fundamental issues concerning the method of theology, to which we should constantly refer, as to a great source of guidelines for today. Let us focus then, on certain statements which appeared in past centuries and which discussed the relation between theology and prayer, trying to find the adequate approach to the spiritual and scientific situation in the field of theology in those times. Certainly, it has to be noted, that the present understanding of theology differs considerably from the situation in the past centuries. However, to some extent, the 'substance' of this concept, despite the ongoing evolution, remains constantly the same. Modern theology is different from the old one in this sense, that in Polish circumstances it has, in most cases, become an academic study pursued at university. This, in turn, imposes new demands, especially with reference to the scholarship of theology, which, on the other hand, does not exclude the need to maintain its sacred character that may be difficult to preserve under the pressure of generally secular academic standards. This pressure does not alter anything and cannot lead to any changes in the nature of theology which holds specific a religious status and which must be irrespectively maintained regardless of the place where theology is studied.

${ }^{1}$ Evagrius Ponticus, Capita practica ad Anatolium: PG 40, 1221. 


\section{Ipsa philosophia Christus}

Today, students of theology begin their studies from "philosophy", that is why it is justified to say, that theological studies are nowadays philosophical and theological studies at the same time. The very reason for such organization is deeply rooted not only in the academic tradition but also in the living experience of the Church. Since philosophy has been a privileged ally of the Church, the latter draws on philosophical achievements, in many different ways, while formulating its religious doctrine. This complex matter would require reconsideration and reflection on the method of efficient and modern combination of philosophy and theology within the theological studies. In the case of many theological issues, there is a lack of successful dialogue between contemporary philosophy and between its present methodological state. ${ }^{2}$ The proposals formulated within the Church teaching, just to mention the encyclical Fides at ratio by John Paul II, has not met with the appropriate acknowledgement among the Church scientific institutions.

It is well known, that before the High Middle Ages the term philosophy had not been defined as one particular field of cognition, but mostly as a way of living and a search for wisdom based on asceticism and contemplation. ${ }^{3}$ Therefore, for a long time the term was applied to characterize those who, in the Church, were especially concerned with compliance with practical evangelical truths and with implementing them in their life and conduct. Philosophizing was synonymous with being a monk (monachum agere). Philosophia denoted monastic life and philosophus referred to a monk. This notion was equivocal to other terms which can be found in Christian language namely: theosophus and philochristus. ${ }^{4}$ In the beginning, theology was also not understood as a method of cognition or a field of knowledge, but rather as a form of prayer. It constituted the foundation of asceticism and led to contemplation. In this sense the term is used by Evagrius Ponticus in the famous principle: "If you are a theologian, you will pray truly. And if you pray truly, you are a theologian."

${ }^{2}$ Cf. H. U. von Balthasar, Regagner une philosophie à partir de la théologie, in: Pour une philosophie chrétienne. Philosophie et théologie, Coll. Le Sycomore, Paris 1983, pp. 175-187.

${ }^{3}$ Cf. H. U. von Balthasar, Christenleben als Philosophie, „Catholica” 14 (1958), pp. 291 304; also in: Sponsa Verbi. Skizzen zur Theologie - II, Einsiedeln 1971, pp. 349-387.

${ }^{4}$ Cf. J. Leclercq, Études sur le vocabulaire monastique du moyen âge, Rome 1961, pp. 4867 (Studia Anselmiana, vol. 48).

${ }^{5}$ Evagrius Ponticus, De oratione 60, PG 79, 1180. 
Clement of Alexandria, who can be recognized as the forerunner of such understanding of philosophy in Christian circles writes: "Philosophy [...] is not a doctrine taught in every school of philosophy. The true philosophy is rather the right attitude not only towards technical wisdom, the aptitude in everyday matters, which we are provided with, but towards wisdom comprising unfaltering knowledge about God's and humans' concerns and being the constant and unchangeable understanding encompassing the present, the past and the future, simply speaking all that we have been taught by the Lord through His descent on earth and by the prophets. [...] This kind of wisdom is called for by philosophy which is the endeavor of the soul to correct reasoning and to pure life." To some extent, St. John Chrysostom summarizes such an approach stating that Christian life is "the highest and most useful philosophy."7 He mentions also the "philosophy of monks" which he declares to be "divine" and "in accordance with Christ's teaching."

When they accentuate philosophy in Christian life, Church Fathers are mainly concerned with the choosing of the path of spiritual purification which enables authentic prayer. Evagrius Ponticus writes in this sense: "Those who want to pray truly, should not only subdue their impulsiveness and concupiscence, but they should also become free from unchaste thought." " One needs to point ou that such an approach was not proposed by Christian thinkers only, but referred to earlier philosophical tradition which treated philosophizing as "readying for death". It was noticed by St. John Climacus (c. 578 - c. 649) who was strongly influenced by classical philosophers.

Analysing the approach to monasticism in the writings of St. John Climacus, Irénée Hausherr pointed out the presence of the notion of theology which he characterises in the following manner: "The true theology requires the death of passion. [...] It is not based on reasoning or speculation. [...] It constitutes the highest goal of monasticism in this life coinciding with the perfection of this state." ${ }^{10}$ Hausherr goes on stating that theology understood in this way

${ }^{6}$ Clement of Alexandria, Stromata 6, 7: PG 9, 276-277.

${ }^{7}$ John Chrysostom, Homiliae XC in Matthaeum 31, 3: PG 57, 374: „Tu vero qui sublimioris utiliorisque philosophiae praecepta audis, non erubescis turpiora quam illi agens?"

${ }^{8}$ John Chrysostom, Homiliae XLIV in Epostolam primam ad Corinthios 6, 3: PG 61, 52.

9 Evagrius Ponticus, De oratione 54: PG 79, 1177.

${ }^{10}$ I. Hausherr, La théologie du monachisme chez saint Jean Climaque, in: Théologie de la vie monastique. Études sur la Tradition patristique, Théologie. Études publiées sous le direction de la Faculté de Théologie S. J. de Lyon-Fourvière, Paris 1961, p. 386. 
is "the ultimate prayer": "It can be called by many different names and denoted by various terms: mystic, empiric, monastic [...] it is all that and many more: everything but dialectics, Scholasticism, syllogistic. The true theology is mute, apart from the fact that it is the worship and adoration. [...] Those who have not experienced God (in this way), can speak about Him only by presumption (as it was expressed by St. Maximus the Confessor); it is the purity which made the disciple a theologian (it seems that any of the translators did not noticed that it refers to St. John) and presented him alone (that is without any professor) with the doctrines concerning the Holy Trinity." ${ }^{11}$

There is no other way or possibility for a monk to become a theologian than to follow the path marked out by St. John, namely the path of inner purity. Christian ascetics appreciated in "philosophy" mainly what they used to call empraktos or diergon which means a study, but in a sense of Latin studium. The subject of their "study" is asceticism; the intensity of its undertaking and practicing is the measure of their pursuit of theology. "Thus, in this sense, theology consists of two elements: the certainty of being called for prayer - theology contemplation, and conviction that it cannot be achieved in any other way but through apatheia." 12

The testimonies derived from Evagrius Ponticus and John Climacus are sufficient to recall the understanding of theology accepted in the ancient Church, which could be widely confirmed by reference to numerous authors of that time. In the Early Middle Ages Venerable Bede referring to Mary, sitting at Jesus's feet, listening to His words, and symbolizing contemplative life, in contrast to Martha who cares about earthly matters, wrote that there is only one theology, namely the one which is the contemplation of God: "Una ergo et sola est theologia, id est contemplatio Dei, cui merito omnia iustificationum merita, universa virtutum studia postponuntur." ${ }^{13}$

Such was basically the way of understanding theology until the $13^{\text {th }}$ century. Theo-logia - sermo de Deo was not based upon the intellectual analyses or scholastic discussions, but emerged out of the practice of contemplation, love and adoration; it was expressed by worship and thanksgiving. It was about the activity of the entire human, which was expressed through inner prayer and through liturgy. Such theology undoubtedly assumes certain cognition, but it is

11 I. Hausherr, La théologie du monachisme chez saint Jean Climaque, p. 390.

12 I. Hausherr, La théologie du monachisme chez saint Jean Climaque, p. 391.

13 Bede Venerable, In Evangelium Lucae expositio 3, 11: PL 92, 471. 
only a tool, a starting point, which will evolve into something more elevated - its proper aim is not to struggle to understand God, but to offer Him thanksgiving and to ask him for help. In short, it consists in giving praise to God, culminating in loving adoration.

It is generally known that in the first half of the $12^{\text {th }}$ century, starting from Abelard, the term theology began to be gradually applied to describe the activity which is more scientific in character. ${ }^{14}$ In the $13^{\text {th }}$ century such understanding would become prevalent. ${ }^{15}$ Treating theology as a science, that is not so strictly based on prayer any more, but which is rather a kind of knowledge stemming from "thinking" would be retained throughout the whole process of development of this Christian way of thinking which was called Scholasticism since it was advocated by "schools" in cities. However, even then it was a matter of major importance to include the aspect of prayer and contemplation within scientific theology, which had its source in a trend which is known today as "monastic theology" as opposed to scholastic theology. ${ }^{16}$ The famous letter Ab Aegyptis argentea by Pope Gregory IX (7 July 1228) addressed to the teachers of theology in Paris may serve as an evidence of these endeavours. ${ }^{17}$

After St. Thomas Aquinas scholastic theology increasingly lost its connection with prayer. In the $15^{\text {th }}$ century theology and prayer definitively "divorced", as it was described by François Vandenbroucke. ${ }^{18}$ Gradually, cognition and love, knowledge and contemplation, and intellectual and spiritual life went on divergent courses, finally resulting in their division. Distinct fields of theological knowledge appeared as a result of this division and it may be argued that its most symptomatic expression was the advent of separate "mystical theology" ("affective theology") whose major goal was to contribute methodically to the development of the soul which could not be accomplished through speculative

${ }^{14}$ Cf. D. Wąsek, Koncepcja teologii Piotra Abelarda, Kraków 2010.

${ }^{15}$ Cf. U. Köpf, Die Anfange der theologischen Wissenschaftstheorie im 13. Jahrhundert, Tübingen 1974.

16 Cf. J. Leclercq, Lamour des lettres et le désir de Dieu. Initiation aux auteurs monastiques du moyen âge, Paris 1957, pp. 197-216.

17 Cf. H. Denifle, A. Chartlain, Chartularium Universitatis Parisensis, vol. 1: Ab anno MCC usque ad annum MCCLXXXVI (Paris 1899), Brussels 1964 (no 59), pp. 114-116.

18 Cf. F. Vandenbroucke, Nouveaux milieu, nouveaux problèmes, du XIIe au XVIe siècle, in: J. Leclercq, F. Vandenbroucke, L. Bouyer, Spiritualité du moyen age, Paris 1961, p. 298. 
theology. ${ }^{19}$ In the $16^{\text {th }}$ century reformers such as Erasmus ${ }^{20}$ and later the Jesuits, within the movement of catholic reformation, acted against this degradation of the vitality of theology. The shift towards the Bible and the tradition, especially the patristic one, was believed to be the key to overcoming the existing dichotomy. St. Ignatius of Loyola and his first disciples, in their academic and formative activity, focused greatly on theology which was commonly known as "positive theology". St. Ignatius emphasizes that positive theology which is based, first of all, on Church Fathers "inspires to love God, our Lord in everything and to serve Him", while on the other hand scholastic theology "determines and explains in context of our times those things which are necessary for eternal salvation and for better revealing and eliminating of all errors and fallacies." ${ }^{21}$ Hieronymus Nadal, a general of Jesuits, deeply influenced by the strong loyalty to the spirit and teachings of St. Ignatius of Loyola, asked suggestively: "Quis agnoscat theologum, qui speculative tantum theologus sit, et non corde ac sensu spiritus intelligat quae intelligit omnia?"22 Therefore, in theology there is an evident need for what is called the "heart" and "spiritual sense". Simply speaking, the study has to become the prayer - erudition has to transform into adoration. We could refer here, once again, to the principle formulated by St. Ignatius in his Spiritual Exercises: "Since it is not the abundance of knowledge that fills and nourishes the soul, but the understanding of things and relishing them."23 The founder of Jesuits surely refers to what St. Bonaventure wrote about St. Francis of Assisi: "Since it is not the abundance of knowledge, but the inner sensing and relishing things that pleases and nourishes the soul." 24

Undoubtedly, the very prayerful and sanctifying value of theology in the $16^{\text {th }}$ century was not so evident in reality, as it was in the $13^{\text {th }}$ century. It had to be reintroduced and defended so that it was reclaimed for good. While in the ancient tradition the terms contemplation and theology were synonymous, in the

19 Cf. J. Gerson, Early works, New York 1998.

${ }^{20}$ Cf. G. Chantraine, «Mystère» et «Philosophie du Christ» selon Erasme. Étude de la lettere à P. Volz et de la «Ratio verae theologiae» (1518), Namur - Gembloux 1971.

${ }^{21}$ Ignatius of Loyola, The Spiritual Exercies, no 363.

22 Excerpta ex apologia P. Hieronymi Nadal pro exercitiis sancti Ignatii 1554/1556, in: Fontes narrativi de s. Ignatio de Loyola et de Societate Iesu initiis, vol. 1: Narrationes scriptae ante annum 1577, eds. D. F. Zapico, C. de Dalmases, Rome 1943, p. 322.

${ }^{23}$ Ignatius of Loyola, The Spiritual Exercies, no 2.

${ }^{24}$ Cf. Bonaventure, Collationes in Hexaemeron 22, 21: "Multa enim scire et nihil gustare quid valet?" 
$16^{\text {th }}$ century they had to be once again interrelated in a synthesis which would meet the criteria of the new times. Although the need for such a synthesis was diagnosed it did not mean that it was instantly put into effect. On the contrary, the scale and pace of the changes were rather marginal. The lack of such synthesis and its methodological application is mostly discernible in the fact that after St. Robert Bellarmine (1542-1621) the time of saint theologians was virtually over.

Theology following scholasticism became predominantly systematic in character and slightly contemplative. The effect of such a transition was the approach towards the mystery of faith and Jesus Christ Himself, which could be described as unilaterally intellectual, conceptual and speculative but not affective, vital and contemplative in the most appropriate sense. It was the conception which led to the divorce mentioned hereinabove, and consequently to the divergent directions of theology and holiness. This process demands analysis by contemporary theologians so that theology and holiness could be happily synthesized once again. ${ }^{25}$ In fact, there are numerous theologians who are rightfully discontented with the present discrepancy between the realities which should constitute one organic whole. That is why they make effort to "resacralise" theology or in other words to make it once again sacra theologia in the full sense of the word. After this short synopsis of certain historical aspects of the study, we would like to indicate a possible way of "resacralisation" of theology, pointing to its internal connection with prayer, the key principle and a tool of sacralisation of every reality.

\section{The internal experience of faith}

First, it is necessary to refer to certain rules, which we will be able to apply later on in the analysis undertaken here, so that, practical consequences could be derived out of them.

Therefore, theology is undoubtedly cognition and a way of apprehension, and what follows is also a science which is grounded on scientific cognition. ${ }^{26}$ Thus, it is an activity of intelligence which assumes, extracts and develops certain

${ }^{25}$ Cf. H. U. von Balthasar, Theologie und Heiligkeit, „Wort und Wahrheit” 3 (1948), pp. 881-896; A. Louf, Un grand docteur monastique: S. Pierre Damien, "Collectanea Ordinis Cisterciensium Reformatorum” 23 (1961), pp. 261-274; J.-P. Torrell, Théologie et sainteté, ”Revue Thomiste" 71 (1971), pp. 205-221.

${ }^{26}$ Cf. Ch. Journet, Introduzione alla teologia, Alba 1956, p. 23-41. 
internal experience from which it cannot be separated. It stems from the fact, that this internal experience is nothing but faith, whereas living faith acts through love, which means that it is the faith conditioned by deeds and conduct based upon love (cf. Galatians 5, 6). As a result, it encompasses a desire and consent and by the same token, prayer, which is a desire and consent by nature. The desire for God is a privileged form assumed by love in temporal life. This aspect of God's love is especially emphasized by St. Augustine, and later, St. Gregory the Great who expressed it in a systematic way, mostly in the commentary to the Song of Songs. ${ }^{27}$

Desirable love is connected with faith and hope, and simultaneously it is the means by which we possess God "in the darkness", as St. Paul points out, and after him, all the mystics. When the possessing becomes the beholding, love will still last and develop although there will be no faith and hope any more. In the meantime - interim as monastic authors used to say - there is the time of desire, aspirations, pursuit and so it is the time of trial as well: the consequence and the expression of the desire for God is prayer which consists in pleading to God and making requests for every man, for the Church, for the whole world and for those who perform significant functions and especially for ourselves. To be able to give God we have to possess Him first, we have to accept Him, but before that, we have to ask for God, since only He offers Himself to man totally gratuitously.

The understanding of prayer as a desire and a request made to God may provide a bond between science and the faith within theology. God is the object of theology - the external object, as compared to man, who can be studied, analysed and described metaphysically. All theology can be done in a very consistent way without referring to faith, at least without referring to living faith which creates a community with God. A philologist can study the Bible as every other text. However, a Christian who experiences his or her faith has to change the approach towards God from the object to the subject, which means that he or she has to identify with Him. It is necessary to meet God spiritually and internally, to hold a conversation with Him in order to reach an interpersonal relation. Man's request to God is necessary since it expresses the need for God, the love of God and the desire for Him. Such a request stands for an act of faith full of prayer, which corresponds with appropriate theological cognition. There is no living faith without the search for God, it must be the pursuit of God and

${ }^{27}$ Cf. Gregorio Magno, Commento al Cantico dei cantici, translated by A. Montanari, Milan 2012. 
the pilgrimage (itinerarium). It is the fundamental message which can be found in the Book of Psalms, which is the superior book of prayer and theology in the Old Testament. ${ }^{28}$

Prayer is the expression of an internal desire of a faithful spirit, which going beyond itself, seeks for something more and Someone else. It is concurrently a constant confirmation of consent to receive a gift in person, a gift which is given and gives itself. It is the practicing of the faith which theological cognition analyses intellectually and on the basis of rational grounds, analyses its subject, that is the content. That is why it is impossible to separate faith from theological knowledge, or faith from prayer, without destroying the integrity of each of them. Theology being scientia fidei is also scientia adorationis. Thus, prayer has the crucial role of linking faith with theology, because experience results from faith. Therefore the existence and continuation of the real theology in the traditional and full sense of the word, namely not only as a pure knowledge, but also as a feeling and a source of experience, is dependent on prayer, which has to mark its beginning - alloquium, as St. Anselm used to say. ${ }^{29}$ In order to make sure that research and contemplative effort is truly theological in character, all must start from beseeching prayer addressed to God. At the end, the study should be concluded by the prayer of acceptance and thanksgiving and by the highest prayer of adoration. Between these two prayerful events, there is a place for intelligence which strives to express, as clearly as possible, what was revealed and what is being discovered now within the subject of faith, which realisation depends on a direct, real and in-person relation with God. The essence of such experience was expressed by St. Ignatius of Loyola: "To smell and to taste with the senses of smell and taste the infinite gentleness and sweetness of the divinity of the soul and of its virtues." ${ }^{30}$

\section{Possible application}

How can we apply the rules mentioned above? We have seen that in the effort of a theologian we can distinguish three consecutive stages of the scientific

${ }^{28}$ Cf. J. M. Vincent, «Qu’est-ce que la théologie?». Une aproche par l'interprétation du Ps 116, "Revue Biblique" 107 (2000), pp. 495-525.

29 Cf. Anselm, Proslogion seu Alloquium de Dei existentia: PL 158, 225.

${ }^{30}$ Ignatius of Loyola, The Spiritual Exercises, no 124. 
procedure which nevertheless determine each other and permeate internally. The first stage can be called the stage of common faith, non-systematised and non-thematised, according to Karl Rahner, which could be defined as the initial perspective on the content revealed and which inspires a prayer of desire and petition. Then, there is the second stage, the stage of theological reflection which analyses the data revealed, expressing them by formulae and systematising them, making it possible to progress from the stage of common perspective to the proper description and organisation of the data revealed. This is the most appropriate meaning of a theological study. The research, however, should not halt at this point, but on the contrary it needs further completion which goes deeper and leads to the discovery of the internal unity of the analysed object. This unity of mysteries in God himself may be discovered only by means of prayerful adoration and contemplation which leaving everything aside directly grasps the whole. As René Voillaume rightly commented: “Theology making God's mysteries more separate and directly understandable has to inspire us to a more lively desire of possessing them in love." ${ }^{31}$ Love, seizing the whole of reality, has a great unifying quality and at the same time it integrates man internally, not only in terms of personality but also in a religious sense. Thanks to that, theology itself gains in significance as a science characterised by internal unity, which was strongly emphasised by St. Thomas Aquinas in his lecture on the nature of theology. ${ }^{32}$ His statement concerning "the sacred doctrine", to some extent exemplar in character, is worth remembering, and it says that it is "velut quaedam impressio divinae scientiae, quae est una simplex omnium." ${ }^{33}$

When these three stages do not complement each other from the beginning to the end, from faith to contemplation, since contemplation is superior to study and it enlivens the faith which stimulates the study, then it is possible to acquire only "theological knowledge", but not theology in the full and final sense of the word, that is the theology which was described at the beginning. Knowledge provided by theology may consist in historical criticism, exegesis and the history of doctrines, or it may involve philosophical reflection in fields that use speculative methods. In any case these are only "auxiliary" fields of theology understood according to its religious logic and its proper goal, which is the

31 R. Voillaume, Come loro, Rome 1964, p. 312.

${ }^{32}$ Cf. Thomas Aquinas, Summa theologiae I q. 1 a. 4.

33 Thomas Aquinas, Summa theologiae I q. 1 a. 4 ad 2. 
sanctifying communion with God that leads in via to the attainment of final salvation.

Therefore, we have to distinguish "theology as a science" and "theology as a prayer", but without separating them or setting them against each other. Thanks to this division it is possible to attain and keep the sense of the mystery of God, who will later express Himself in the way we speak about this mystery. Experience often shows that a theologian can and should not only elucidate mysteries, but rather inspire other people to sense and respect the mystery of God. This feeling has to be attained personally at first, so that it could be passed to others. The sensing and respect towards God actually become as tasting of God, which is the result of faith, humility, love and admiration, namely the most elevated spiritual attitudes. These constitute an element of personal holiness which can later develop creatively, shaping personal and ecclesial attitudes. It involves the essential openness to prayer which is contemplative and full of adoration. It is enough to remind here, that the prayer of straightforwardness, humility and obedience in front of God, and of acceptance of Him and his mysteries and his demands, is the most appropriate expression of love which consists in the profound desire to possess and taste God. When it is the love which possesses God, then it also admires Him and thanks Him for the knowledge of Him, which is graciously granted to the faithful so that they can follow the road of effective sanctification. ${ }^{34}$

Thanksgiving to God for the knowledge about Himself, which He graciously revealed to the faithful, was a question of major importance in the theology of Church Fathers. In the times when Christians, day by day, experienced that the world in which they live is not yet Christian, Church Fathers emphasized that the faithful should notice their special privilege, which was the access to the truth revealed, and that they should cherish this blessing. They were inspired by the enthusiastic statement of St. Peter from the First Epistle: "But you are a chosen race, a kingdom of priests, a holy nation, a people to be a personal possession to sing the praises of God who called you out of the darkness into his wonderful light" (2:9).

Today, even if our direct environment is Christian, we are aware that the world is full of people who do not know God and who do not love Him sufficiently. Therefore, do we appreciate adequately these fundamental blessings which we can enjoy, namely love, the possibility of knowing the true God and

${ }^{34}$ Cf. A. Chapelle, À lécole de la théologie, Brussels 2013, pp. 275-288. 
theology - scientia salutis - that is the knowledge which helps us to attain salvation? Let us think about various efforts made by the Church, struggling against accusations of backwardness and the abuse of its position, to provide the clergy and lay people with the opportunity for intellectual cognition - scientific in the full sense of the word - of the mysteries of God and to show how those mysteries ought to shape the way of personal and communal life. Also, as Christians, we should ask ourselves whether it is really the matter of truth that is loved spontaneously for its unusual coherence and which is loved even more because it has been known better? Is it the truth for which we are grateful, bearing in mind the salutary good that we received and the privileges resulting from it, especially the privilege of the clear road to salvation? Today we can often hear about the need for "kneeling theology" as Hans Urs von Balthasar described it. But we know, as well, that such theology should be the aim of "sitting theology" which arises from the study at home or at the library, or which is attained in the auditorium by listening to the real masters. The latter is indispensable, however it has only a preparatory character in relation to the former. There is also "standing theology" - that is theology developed in the presence of God, in front of His majesty. This internal prayer of silent adoration realizes itself in the Church together with communal and public celebration of liturgical worship. This, on the other hand, is a form of prayer which is supposed to transform finally into "singing theology". Ultimately, as St. Augustine points out, the eternal singing of "Hallelujah" will crown the faithful journey of humankind and theology as well since it stems from faith: "Let us sing alleluia here on earth, while we still live in anxiety, so that we may sing it one day in heaven in full security. [...] So, then, my brothers, let us sing now, not in order to enjoy a life of leisure, but in order to lighten our labours. [...] Sing, but keep going."35

Observing religious attitude in life is and always will be determined by our former and habitual involvement which constitutes, to some extent, an existential option which characterises the existence and actions of a believer. This perspective is strongly emphasised by the Catholic tradition which approaches religiousness as the attitude which engulfs and orders everything. ${ }^{36} \mathrm{Zeal}$, magnanimity, devotion to prayer are all superfluous when we have already devoted to theological study and when we strive to achieve certain scientific

35 Augustine, Sermo 256, 3: PL 38, 1193.

${ }^{36}$ Cf. B. de Margerie, Mélanges anthropologiques à la lumière de saint Thomas d'Aquin, Paris 1993, pp. 51-64. 
goals. Furthermore, at such a moment, the best thing to do is to sit comfortably and assiduously at the desk and not to treat theology as a prayer, then we will be able to devote to theology as to a science and to carry intellectual research. Magnanimity, expectation and love towards God have to be previously rooted in our existential and spiritual attitude as well as in our study. Without these qualities we had better not undertake theological involvement, since it could be done totally in vain. It could be deprived of its very sense, which is an interior personal relation with God. It would be strictly an intellectual exercise, external and not compliant with the life of faith. On the contrary, if we have already had love in us, then we will learn more and we will love the One, with whom we will be more familiar, more. This has its source in the reflections of the Medieval spiritual masters who stressed that: "Amor oculus est et amare videre

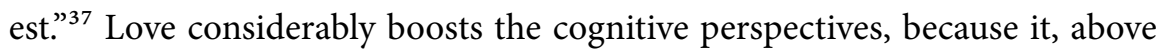
all, brings us closer to the heart of theology, that is to God. If we are supposed to study God, and everything else according to His perspective, we have to draw nearer to Him. Then everything that we can hear about God from theologians, mystics and even from those who reject Him, all that will be received by us in a different way. It will be more credible and inspiring.

If an academic and a student live on love, if they possess this indispensable internal disposition opening to theology, they will be able to react spontaneously to everything like spiritual people, or in other words, like true theologians. The study will become for them a sparkle which initially elicits and later shapes the interpersonal relation, which creates bonds, inspires the prayer of consent and thanksgiving, and encourages to holly deeds. It seems justified to refer in this place to the principle which was applied by St. Thomas Aquinas several times. Inspired by the verses of the psalm, he uses the rule in the second part of Summa Theologica for example when commenting on eremites. The objection commonly raised against hermits is that they are not devoted to God in the right way since they do not have chance to show their obedience. Thomas replies that in the beginning, in the coenobitic phase of life, hermits were so obedient that they reached such compliance which could do without a hierarchical superior. They did not need to perform particular positive acts of submission of their will to the will of the superior who would be beside them: "Habent enim oboedientia in praeparatione animi." ${ }^{38}$ The same holds true for the people who devote them-

\footnotetext{
37 Richard of Saint Victor, De gradibus charitatis: PL 196, 1203.

38 Thomas Aquinas, Summa theologiae II-II q. 188 a. 8 ad 3.
} 
selves to theological study. Their theology will be kneeling, standing or singing theology, hence the theology of intimacy with God, if they authentically knelt, stood and sang in front of God before they proceeded to study. The study will be the continuation of their preparation to contemplative prayer. Their desires during the study. Even the desires seemingly remote from God's mystery, will turn towards Him: "Praeparationem cordis eorum exaudivit" (Psalm 10:17). When the stage of proper study has been finished then the attitude of prayer is resumed and the studied content becomes the essence of spiritual life and inspiration for everyday life in which the sanctifying work finds its expression.

We can find the explanation of this process in the reflections of St. Thomas Aquinas. Analysing the relations between "active life" and "contemplative life" he exposes that what he calls a "doctrine" is the teaching of theology as the work of active life which has its source in contemplative life. It results, first of all, from the subject of this teaching which is God who is being known and who lets us know; secondly from the object who has to be in the condition of internal zeal and whose "doctrine" will be a consequence, expression, emanation. ${ }^{39}$ For the substantiation of the stated question Aquinas quotes the meaningful line of the psalm: "Memoriam abundantiae suavitatis tuae eructabunt" (Psalm 144:7). It speaks about the memory which St. John Cassian described as incessant: "ad perpetuam Dei memoriam." ${ }^{40}$ Such memory emanating with significantly exercised result which is internal delight (abundantiae suavitatis), transforms into a testimony which leads to Him through the eructation, which is a biblical symbol of enthusiasm and love. It has to be noticed that this refers both to those whose undertake this great task within the Church.

What St. Thomas Aquinas remarks on those who teach "saint doctrine" is equally true for those who listen to that preaching for two reasons, namely for the reason of God and His mysteries which constitute the subject of cognition, and for the reason of internal disposition of the subject. The same involvement is expected from the person who teaches the "doctrine" and from the person who receives it and ponders upon it. For this reason two significant and essential elements of the study, that is lesson and reading ought to end with a prayer, namely they should extend into contemplation, into relishing the truth - gaudium de veritate, and into personal openness. The idea that prayer has to be taught as well is not utopian and there are numerous examples which confirm this need.

\footnotetext{
39 Thomas Aquinas, Summa theologiae II-II q. 188 a. 6.

${ }^{40}$ John Cassian, Collationes 10, 10: PL 49, 832.
} 
That is why it is, by all means, sensible to make prayer one of the fundamental theological topics. However, in this matter a lot depends on the teachers (but also on the students), on their enthusiasm inspired by the access to the truth which they hand down to their students. The spiritual reading of the notes taken down during the lectures is also possible. This possibility is supported by recommendable publications, not only classical but also modern, which are growing in number, and which often stay hidden and have not been sufficiently appreciated yet. The present generation is privileged in this respect although it does not often discern this fact. Such a wide selection of theological resources was not available twenty years ago. If an academic lecture (lesson) is collective in a way, impersonal to large extent and somehow universal, reading on the other hand can be, and is, personal and internal. It is a moment favourable for reflection on that which was taught or for meditation upon a book which concerns the field. This is what restores the character of personal exercise in impersonal teaching, which otherwise could only be fruitless.

\section{Conclusions}

Although the principles formulated here are obvious to some extent, there is no simple solution to the problem posed in this paper and it cannot be achieved once and for all. Nevertheless it is certain that such solution exists. Everyone has to discover personally what such a solution consists in, what its conditions are and what particular requirements it involves. In this study we have made an attempt to show only a possible way to find the solution and boundaries within which it can be found. All in all, it can be said that the solution consists in using theological knowledge to serve theology, which appropriately to its full and traditional sense, is total and completed only then when it constitutes a foundation of piety and when it is directed at prayer. What characterizes this attitude in these two states of the "preparation" of the heart and its "flowing out" - eructation - is zeal. This zeal, which we ought to raise, shape and constantly strengthen throughout all our life and in all our studies and lectures given, is what gives our theology not only brightness. It depends considerably on intelligence but zeal also determines its vitality and points out to its internal coherence; it penetrates our internal life and makes it possible to possess and to belong to God at the same time. This zeal, since it is a gift, has to be asked for. It must be cultivated in every possible way and from the very beginning, since 
it helps to practice love towards God and our neighbor. Therefore such elements as brotherly life, collective work and collective study, care for the service, gentleness of relations and respect for personality of another person are so significant. St. Albert the Great formulated a recommendation which was especially followed by Dominican friars: "In dulcetudine societatis quaerere veritatem." ${ }^{1}$

The same goes for apostolic zeal which is strictly related to theology although it is an issue which deserves separate analysis. At this point it is enough to remark that apostolate verifies theology. It is not the rhetorical art, achieved eloquence, or even sophisticated speculation even if they are all at high level, that makes the argument convincing. It is the convincing tone that is vital but also the appropriate stressing of the truth, which can even find a special way of expression. Modulation of voice is important as well, however on condition that it is not in contrast with the internal experience of the speaker. The truth which is being communicated must be based on existential experience and must constitute its expression. ${ }^{42}$ It is not of much significance that a statement wins the audience's confidence, induces to affirmation, puts to shame or moves, if it does not communicate the truth. This truth needs to show through the authenticity of the speaker and his experience, whether he believes with all his being and whether he was internally transformed by the content which he delivers. We sometimes see or listen to a particular lecturer or a preacher and are moved to question whether he really believes what he says. Some might recite the thoughts of someone else and recall them without personal reference to them. Their testimony is superficial and it will not convince or convert anyone. To avoid such situations it is necessary to practice theology with enthusiasm and joy: gaudium de veritate, in youth and simplicity of heart undivided, which is whole devoted to God, in other words, which is efficiently following the way of holiness. Shortly speaking, an effort has to be made that theology remained sacra.

${ }^{41}$ Cf. Y. Congar, Chercher la vérité dans la douceur de la communauté, „La Vie Spirituelle” 81 (2001), pp. 285-297.

${ }^{42}$ Cf. J. Królikowski, Jaka prawda? Jaka wolność? Propozycje do dyskusji z kultura wspótczesna, „Sympozjum” 2 (1998) no. 2, pp. 117-129. 


\section{Bibliography}

Anselm, Proslogion seu Alloquium de Dei existentia: PL 158, 241-248.

Balthasar H. U. von, Theologie und Heiligkeit, "Wort und Wahrheit” 3 (1948), pp. 881-896.

Balthasar H. U. von, Christenleben als Philosophie, “Catholica” 14 (1958), pp. 291-304.

Balthasar H. U. von, Sponsa Verbi. Skizzen zur Theologie - II, Einsiedeln 1971.

Balthasar H. U. von, Regagner une philosophie à partir de la théologie, in: Pour une philosophie chrétienne. Philosophie et théologie, Coll. Le Sycomore, Paris - Namur 1983, pp. 175-187.

Bonaventure, Collationes in Hexaemeron.

Chantraine G., "Mystère» et «Philosophie du Christ» selon Erasme. Étude de la lettere à P. Volz et de la «Ratio verae theologiae» (1518), Namur - Gembloux 1971.

Chapelle A., À l'école de la théologie, Bruxelles 2013.

Clement of Alexandria, Stromata: PG 9, 9-601.

Congar Y., Chercher la vérité dans la douceur de la communauté, "La Vie Spirituelle" 81 (2001) no 735, pp. 285-297.

Bede Venerable, In Evangelium Lucae expositio: PL 92, 633-938.

Evagrius Ponticus, Capita practica ad Anatolium: PG 40, 1219-1250.

Evagrius Ponticus, De oratione: PG 79, 1166-1197.

Gerson J., Early works, New York 1998.

Gregorio Magno, Commento al Cantico dei cantici, introducione, traduzione e note a cura di A. Montanari, Milano 2012.

Hausherr I., La théologie du monachisme chez saint Jean Climaque, in: Théologie de la vie monastique. Études sur la Tradition patristique, Théologie. Études publiées sous le direction de la Faculté de Théologie S. J. de Lyon-Fourvière, Paris 1961, pp. 385-410.

Igatius of Loyola, The Spiritual Exercies.

John Chrysostom, Homiliae XC in Matthaeum: PG 57, 13-463.

John Chrysostom, Homiliae XLIV in Epostolam Primam ad Corinthios: PG 61, 9-379.

Fontes narrativi de s. Ignatio de Loyola et de Societate Iesu initiis, vol. 1: Narrationes scriptae ante annum 1577, eds. D. F. Zapico, C. de Dalmases, Romae 1943.

Journet Ch., Introduzione alla teologia, Alba 1956.

Köpf U., Die Anfange der theologischen Wissenschaftstheorie im 13. Jahrhundert, Tübingen 1974.

Królikowski J., Jaka prawda? Jaka wolność? Propozycje do dyskusji z kultura współczesna, „Sympozjum” 2 (1998) no 2, pp. 117-129.

Leclercq J., Études sur le vocabulaire monastique du moyen âge, Roma 1961, pp. 48-67 (Studia Anselmiana, t. 48).

Leclercq J., L'amour des lettres et le désir de Dieu. Initiation aux auteurs monastiques du moyen âge, Paris 1957. 
Leclercq J., Vandenbroucke F., Bouyer L., Spiritualité du moyen age, Paris 1961.

Louf A., Un grand docteur monastique: S. Pierre Damien, "Collectanea Ordinis Cisterciensium Reformatorum" 23 (1961), pp. 261-274.

Margerie B. de, Mélanges anthropologiques à la lumière de saint Thomas d'Aquin, Paris 1993.

Richard of Saint Victor, De gradibus charitatis: PL 196, 1207-1224.

Thomas Aquinas, Summa theologiae.

Torrell J.-P., Théologie et sainteté, "Revue Thomiste" 71 (1971), pp. 205-221.

Vincent J. M., "Qu'est-ce que la théologie?». Une aproche par l'interprétation du Ps 116, "Revue Biblique" 107 (2000), pp. 495-525.

Voillaume R., Come loro, Roma 1964.

Wąsek D., Koncepcja teologii Piotra Abelarda, Kraków 2010. 